\title{
فى هندالعدد..
}

人

$$
\text { إطار متزمح للتمبيم التعليمى }
$$

-

N

$$
\text { تعدد أنساط الإبحار وإثداد البروجيات التعليمية }
$$

○

$$
\text { هملير تصميسم برالمج الاكبيسونز التدريبية }
$$

○

$$
\text { ثروة الآتصالات الاتفيرة واستشراف المستبل }
$$

-

(1)

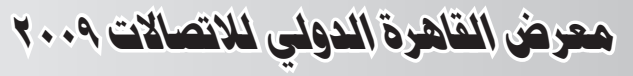

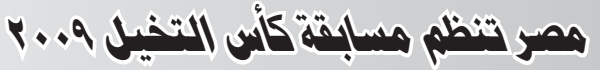

-

$\varepsilon \varepsilon$

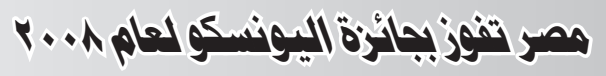

○

\&\&

$$
\text { تقريز وتوصيات الرعتمر العلمي الخاهس عشر }
$$

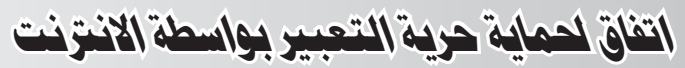

YH

$$
\text { اتفاق لحماية حرية التبعير براسطة الآتزنت }
$$

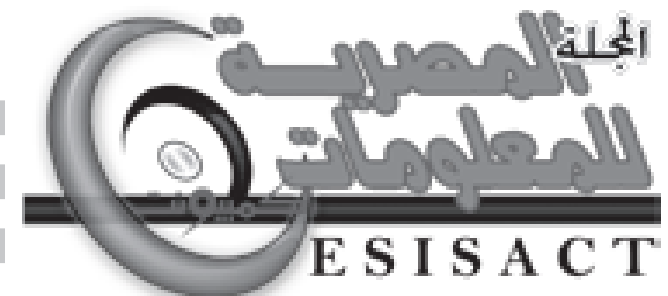

\section{MANAGEMENT GAMES IN BUSINESS EDUCATION \\ -}

\section{BUSINESS INTELLIGENCE ARCITICTURE}

13 